\title{
DETERMINAN KUALITAS REVIU DAN IMPLIKASINYA TERHADAP KUALITAS LAPORAN KEUANGAN PEMERINTAH DAERAH
}

\author{
Aditya Maulana ${ }^{1}$, Ali Djamhuri² \& Lilik Purwanti ${ }^{3}$ \\ ${ }^{1}$ Inspektorat Kota Pasuruan, Indonesia, \\ 2,3 Universitas Brawijaya Malang, Indonesia \\ E-mail: abi.danishkoe@gmail.com
}

\begin{abstract}
Abstrak: Determinan Kualitas Reviu dan Implikasinya terhadap Kualitas Laporan Keuangan Pemerintah Daerah. Penelitian ini bertujuan untuk menjelaskan pengaruh dari kompetensi, komitmen organisasi dan sistem pengendalian intern (SPI) terhadap kualitas reviu dan implikasinya terhadap kualitas Laporan Keuangan Pemerintah Daerah (LKPD). Reviu dalam hal ini adalah reviu LKPD. Penelitian ini menggunakan analisis regresi linier berganda untuk menguji pengaruh kompetensi, komitmen organisasi dan sistem pengendalian intern terhadap kualitas reviu, sedangkan uji terhadap pengaruh kualitas reviu terhadap kualitas LKPD menggunakan analisis regresi linier sederhana. Penelitian dilakukan terhadap aparat pengawas (auditor APIP) pada inspektorat daerah di 8 (delapan) wilayah eks Karesidenan Malang. Hasil penelitian membuktikan bahwa kualitas reviu dipengaruhi oleh kompetensi, komitmen organisasi dan sistem pengendalian intern dan kualitas reviu berpengaruh terhadap kualitas LKPD.
\end{abstract}

Kata kunci: Kompetensi, komitmen organisasi, sistem pengendalian intern, kualitas reviu, kualitas LKPD.

\begin{abstract}
The Determinants of Review Quality and Its Implication to Local Government's Financial Statements Quality. This study aimed to explain the effect of competencies, organizational commitment and internal control system to the quality of the review and the implication to the quality of local government's financial statements (LKPD). The review in this context is the review of LKPD. This research used multiple linear regression analysis to examine the effect of competencies, organizational commitment and internal control system to the quality of the review of LKPD, and the test to the effect of quality of the review on the quality of LKPD used simple linear regression analysis. Research objects are the internal auditor of the regional inspectorate on eight areas in ex-Malang residence. The results of the study indicate that the quality of the review affected by the competencies, organizational commitment and internal control system and quality of the review effect the quality of LKPD.
\end{abstract}

Keywords: competencies, organizational commitment, internal control system, quality of the review, quality of local government's financial statements.

\section{PENDAHULUAN}

Aparat Pengawas Intern Pemerintah (APIP) ditugaskan melaksanakan reviu atas laporan keuangan untuk memberikan keyakinan terhadap informasi yang disajikan. Hal tersebut tertuang dalam Peraturan Pemerintah (PP) Nomor 8 Tahun 2006 pada
Pasal 33 ayat (3). Reviu merupakan salah satu tugas yang dilaksanakan oleh APIP selain audit, evaluasi, konsultansi dan kegiatan pengawasan lain. Dalam rangka pelaksanaan reviu atas Laporan Keuangan Pemerintah Daerah (LKPD) pemerintah menerbitkan Peraturan Menteri Dalam Negeri 
(Permendagri) Nomor 4 Tahun 2008 tentang Pedoman Pelaksanaan Reviu atas LKPD.

Reviu dilaksanakan dalam rangka membantu Kepala Daerah untuk menghasilkan LKPD yang berkualitas. Laporan keuangan adalah bukti pertanggungjawaban yang diwajibkan oleh pemerintah pusat kepada pemerintah daerah atas pengelolaan keuangan daerahnya. Menurut Harahap (2009:145) laporan keuangan yang disusun tersebut haruslah laporan keuangan yang memenuhi karakteristik kualitatif sehingga dapat sesuai dengan keinginan pengguna, yaitu relevan, andal, dapat dibandingkan dan dapat dipahami. Dalam PP Nomor 71 Tahun 2010 dijelaskan tentang masing-masing karakteristik kualitatif tersebut. Relevan dalam hal ini berarti bahwa informasi yang terkandung dalam laporan keuangan dapat dimanfaatkan oleh pengguna dalam pengambilan keputusan. Andal mengandung arti bahwa informasi dalam laporan keuangan disajikan secara jujur berdasarkan fakta, tidak menyesatkan serta dapat diverifikasi. Dapat dibandingkan artinya laporan keuangan tersebut dapat disandingkan untuk bahan perbandingan dengan laporan keuangan periode sebelumnya maupun laporan keuangan entitas pelaporan lainnya. Laporan keuangan yang dapat dipahami artinya bahwa laporan keuangan tersebut menggunakan bahasa dan istilah umum yang sering digunakan sehingga mudah dibaca dan dipahami oleh pengguna.

Pemerintah daerah memerintahkan inspektorat daerah sebagai APIP untuk melakukan reviu atas LKPD sebelum diserahkan kepada Badan Pemeriksa
Keuangan (BPK) untuk diaudit. Permendagri Nomor 4 Tahun 2008 menjabarkan reviu atas LKPD sebagai kegiatan yang dilaksanakan oleh inspektorat yang terdiri dari prosedur penelusuran angka, permintaan keterangan terhadap entitas misalnya, apabila ditemukan angka yang tidak sesuai dan prosedur analitis untuk dapat meyakini secara terbatas bahwa laporan keuangan tidak memerlukan modifikasi material sehingga laporan tersebut tersaji berdasarkan Sistem Pengendalian Intern (SPI) yang memadai dan sesuai Standar Akuntansi Pemerintahan (SAP).

Untuk dapat membantu menghasilkan laporan keuangan yang berkualitas, reviu yang dilaksanakan auditor APIP haruslah reviu yang berkualitas. Penelitian Widyarini (2015) menyebutkan bahwa kualitas reviu dinilai berdasarkan pemenuhan komponen yang terdapat dalam Standar Reviu atas LKPD (Peraturan Menteri Keuangan Nomor 8 Tahun 2015), yaitu 1) ruang lingkup reviu, yaitu prosedur penelusuran angka, permintaan keterangan dan analitis; 2) waktu pelaksanaan reviu bersamaan atau selama pelaksanaan anggaran dan penyusunan LKPD; 3) kompetensi pereviu, diantaranya pemahaman SAP, SAPD, proses bisnis dan kegiatan pokok entitas, teknik komunikasi serta analisis basis data; 4) tahapan reviu yang terdiri dari perencanaan, pelaksanaan dan pelaporan; 5) Kertas Kerja Reviu (KKR), pendokumentasian seluruh prosedur reviu yang dilaksanakan; dan terakhir 6) pelaporan reviu, yaitu Laporan Hasil Reviu yang didalamnya terdapat Pernyataan Telah Direviu dari Inspektur sebagai dasar pembuatan Pernyataan Tanggung Jawab Kepala Daerah yang 
menyertai Laporan Keuangan. Hasil yang diharapkan dari reviu berkualitas adalah rekomendasi yang tepat dalam rangka peningkatan kualitas LKPD.

Penelitian Amirullah et al. (2010) menyebutkan bahwa reviu atas LKPD dipengaruhi oleh kompetensi dan komitmen organisasi dari auditor pelaksana reviu. Hal ini didukung penelitian Eda et al. (2017) yang juga menyebutkan bahwa kompetensi dari auditor APIP berpengaruh positif terhadap kualitas reviu. Kompetensi menurut Alim, et al. (2007) adalah pengetahuan, keterampilan dan kemampuan yang berkaitan dengan pekerjaan serta kemampuan yang dibutuhkan dalam pekerjaan yang tidak rutin. Ashton (1991) merujuk literatur psikologi menjelaskan bahwa peningkatan kompetensi membutuhkan pengetahuan yang spesifik dan lamanya pengalaman dalam suatu pekerjaan. Hal ini sesuai dengan Tandiontong (2016:172) yang menyebutkan bahwa kompetensi berkaitan dengan keahlian, pengalaman dan pengetahuan.

Oleh karenanya seorang auditor dikatakan kompeten apabila memiliki pengetahuan, pelatihan serta pengalaman yang cukup dalam audit sehingga mampu melaksanakan tugasnya dengan baik dan menghasilkan audit yang berkualitas. Hal ini sesuai dengan Standar Audit Intern Pemerintah Indonesia (SAIPI) yang menyatakan bahwa auditor harus memiliki pendidikan, pengetahuan, keahlian dan keterampilan, pengalaman serta kompetensi lain yang diperlukan dalam pelaksanaan tugasnya.

Komitmen organisasi dijelaskan Robbins \& Judge (2009) sebagai 'level di mana seorang karyawan diidentikkan dengan suatu perusahaan dan tujuannya, dan keinginan untuk tetap bertahan sebagai bagian dari suatu organisasi'. Kepemilikan komitmen organisasi yang tinggi pada seseorang akan berdampak terhadap sikap positif yang akan ditunjukkannya terhadap perusahaan dengan memberikan segala kemampuan dan upayanya dalam rangka keberhasilan pencapaian tujuan perusahaan. Windsor dan Ashkanasy (1995) menyebutkan tiga komponen dalam membedakan komitmen organisasi, yaitu: 1) komitmen afektif, yaitu komitmen berdasarkan perasaan emosional untuk selalu menjadi bagian dalam perusahaan; 2) komitmen kontinum, yaitu komitmen yang didasari perhitungan untung rugi dengan keberadaannya dalam perusahaan; 3) komitmen normatif, yaitu komitmen yang timbul dikarenakan adanya paksaan dari pihak lain agar tetap menjadi bagian dari perusahaan.

Faktor lain yang tidak kalah penting dalam menghasilkan reviu yang berkualitas adalah sistem pengendalian intern (SPI). Hal ini didukung penelitian Manaf et al. (2014) yang menyebutkan bahwa pemahaman auditor terhadap sistem pengendalian intern berpengaruh terhadap proses reviu LKPD. Sistem pengendalian intern adalah suatu sistem yang terintegrasi yang dilaksanakan secara kontinyu dalam semua tindakan dan kegiatan yang dilakukan aparat pemerintah, mulai pimpinan sampai dengan staf, dalam penyelenggaraan pemerintahan. Hal ini dijelaskan lebih lanjut dalam PP Nomor 60 Tahun 2008 tentang Sistem Pengendalian Intern Pemerintah (SPIP) yang menyebutkan bahwa SPIP terdiri dari lima unsur, yaitu lingkungan pengendalian, penilaian risiko, aktivitas pengendalian, informasi dan 


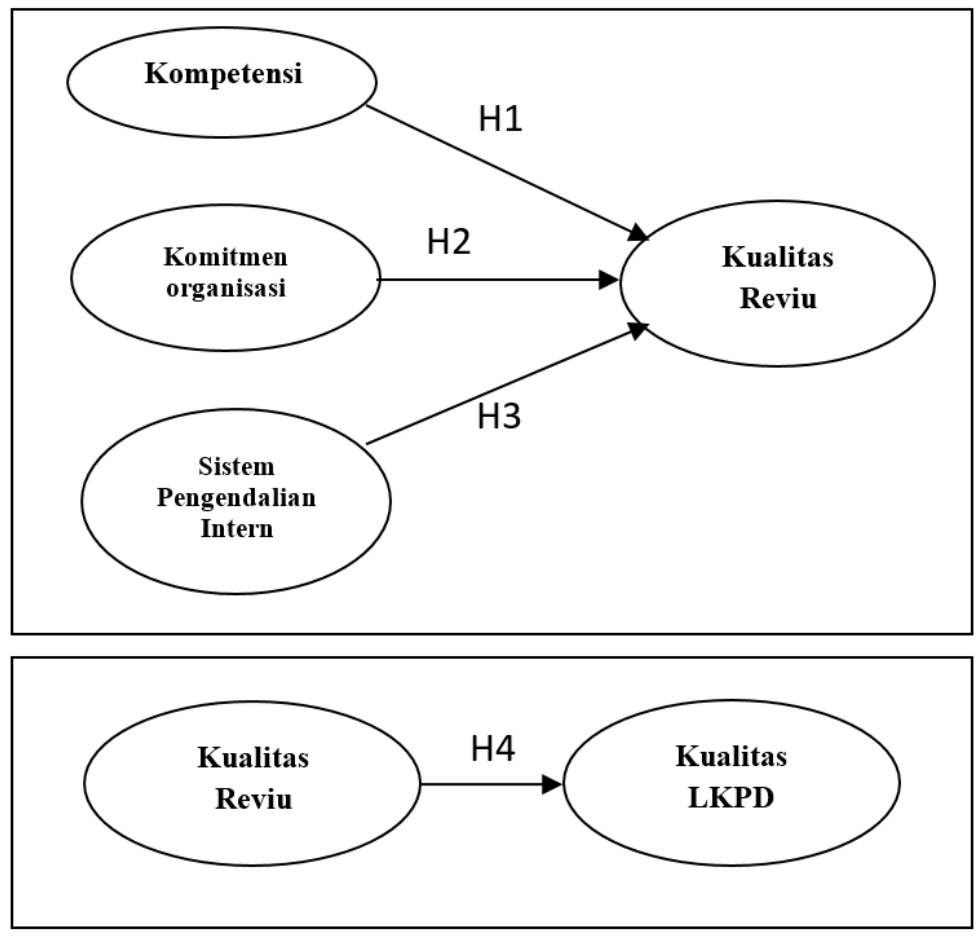

Gambar 1. Model Penelitian

komunikasi serta kegiatan pemantauan pengendalian.

Pemerintah menugaskan Inspektorat Jenderal, Inspektorat Provinsi, Inspektorat Kabupaten/Kota dan Badan Pengawas Keuangan dan Pembangunan (BPKP) sebagai APIP untuk melaksanakan pengawasan terhadap penyelenggaraan tugas dan fungsi instansi pemerintah lainnya. Hal ini sesuai dengan peran APIP yang efektif yang disebutkan oleh Marganingsih dan Martani (2010) di antaranya adalah memberikan keyakinan yang memadai atas ketaatan, efisiensi, efektivitas maupun kehematan dalam pencapaian tujuan instansi pemerintah; memberikan peringatan dini serta meningkatkan efektivitas manajemen risiko dalam pelaksanaan tugas instansi pemerintah; meningkatkan serta menjaga kualitas tata kelola penyelenggaraan tugas dan fungsi instansi pemerintah. Implementasi SPI yang memadai dalam kegiatan reviu LKPD mengandung arti bahwa tujuan reviu LKPD dicapai melalui kegiatan yang efektif dan efisien, menghasilkan laporan keuangan yang handal, pengamanan aset negara yang memadai serta ketaatan terhadap peraturan perundangan.

Dalam rangka memastikan auditor APIP berkompeten dan bertanggungjawab dalam pelaksanaan tugasnya, pemerintah menetapkan jabatan fungsional pengawas yang sementara ini terdiri dari jabatan fungsional auditor (JFA), jabatan fungsional pengawas penyelenggaraan urusan pemerintahan daerah (JFP2UPD) dan jabatan fungsional pengawas kepegawaian. Pengangkatan auditor inspektorat ke dalam jabatan fungsional ini diharapkan agar auditor terdiri dari orang yang benar-benar kompeten sesuai bidang keahlian yang dibutuhkan dan memiliki komitmen organisasi yang tinggi. Hal ini dikarenakan jabatan fungsional pengawas memiliki kode 
Tabel 1. Data Opini atas LKPD Tahun 2011-2015 di Wilayah Eks Karesidenan Malang

\begin{tabular}{lccccc}
\hline \multicolumn{1}{c}{ Kota/Kab } & 2011 & 2012 & 2013 & 2014 & 2015 \\
\hline Kota Pasuruan & WDP & WDP & WDP & WDP & WDP \\
Kota Probolinggo & WTP DPP & WTP & WTP DPP & WDP & WDP \\
Kota Batu & WDP & WDP & WDP & WDP & WTP \\
Kota Malang & WTP DPP & WTP & WTP DPP & WTP DPP & WTP \\
Kabupaten Malang & WDP & WDP & WDP & WTP DPP & WTP \\
Kabupaten Probolinggo & WDP & WDP & WTP DPP & WTP DPP & WTP \\
Kabupaten Pasuruan & WDP & WDP & WTP DPP & WTP DPP & WTP \\
Kabupaten Lumajang & WDP & WDP & WDP & WTP DPP & WTP \\
\hline
\end{tabular}

Sumber: BPK RI,

etik dan standar audit yang harus dipatuhi dan dijalankan oleh auditor APIP sehingga mendapatkan hasil yang berkualitas. Berdasarkan uraian di atas, penelitian ini mengembangkan dua model penelitian yang dapat dilihat di Gambar 1.

\section{METODE}

Penelitian ini termasuk dalam,.,penelitian penjelasan (explanatory research) yang tujuannya menjelaskan fenomena yang terjadi berdasarkan hubungan antara variabel independen kompetensi, komitmen organisasi dan sistem pengendalian intern dengan variabel dependen kualitas reviu, serta hubungan antara variabel independen kualitas reviu dengan variabel dependen kualitas LKPD. Penelitian ini dilaksanakan pada inspektorat daerah di wilayah eks Karesidenan Malang, yaitu Kabupaten Malang, Kota Malang, Kabupaten Pasuruan, Kota Pasuruan, Kabupaten Probolinggo, Kota Probolinggo, Kabupaten Lumajang dan Kota Batu. Pemilihan wilayah eks Karesidenan Malang diharapkan dapat mewakili daerah lain karena berdasarkan hasil opini atas LKPD yang didapatkan 8 (delapan) wilayah terdiri dari tren yang berbeda (Tabel 1). Ada wilayah yang dalam kurun tahun 2011-2015 mendapatkan opini WTP, ada yang selalu mendapatkan opini WDP, ada daerah yang mendapatkan peningkatan opini dari WDP menjadi WTP dan bahkan ada wilayah yang mengalami penurunan opini dari WTP menjadi WDP.

Populasi dari penelitian ini adalah seluruh aparat pengawas, baik itu auditor yang terdiri dari pejabat fungsional auditor dan pejabat fungsional P2UPD maupun staf yang ditugaskan sebagai aparat pengawas. Penelitian ini menggunakan metode sensus, yaitu keseluruhan populasi digunakan sebagai sampel, untuk mendapatkan hasil yang lebih presisi (Nuryaman dan Christina, 2015: 104).

Sumber data penelitian ini adalah data primer yang didapatkan langsung dari kuesioner yang diisi oleh responden sebanyak 119 orang. Kuesioner disebarkan langsung kepada responden untuk diisi dalam waktu 3 (tiga) minggu. Kuesioner yang digunakan menggunakan skala Likert lima poin untuk penilaiannya, yaitu 1 = sangat tidak setuju, 2 = tidak setuju, $3=$ netral, $4=$ setuju, dan 5 = sangat setuju.

Penelitian ini menggunakan dua model penelitian. Model penelitian pertama menggunakan 3 (tiga) variabel independen, yaitu kompetensi (KA), komitmen organisasi (KO) dan sistem pengendalian intern (SPI) 
dan 1 (satu) variabel dependen yaitu kualitas reviu (KR) dianalisis dengan metode analisis regresi linier berganda. Model penelitian kedua menggunakan kualitas reviu (KR) sebagai variabel independen dan 1 (satu) variabel dependen yaitu kualitas LKPD (KL) dianalisis menggunakan metode analisis regresi linier sederhana.

Kompetensi diukur berdasarkan indikator pengalaman, pendidikan dan pengetahuan yang dijabarkan dalam dua belas pernyataan yang diukur dengan skala Likert. Komitmen organisasi diukur berdasarkan indikator yang digunakan dalam instrumen Mowday, et al. (1979) yaitu 1) keyakinan dan penerimaan yang kuat terhadap tujuan dan 'nilai' organisasi; 2) kesediaan untuk mengerahkan usaha maksimal atas nama organisasi; dan 3) keinginan yang kuat untuk tetap menjadi bagian dari organisasi. Instrumen pengukuran variabel komitmen organisasi terdiri dari sembilan pernyataan yang diukur dengan skala Likert.

Sistem pengendalian intern diukur berdasarkan indikator lima unsur pengendalian, yang meliputi lingkungan pengendalian, penilaian risiko, aktivitas pengendalian, komunikasi dan informasi, dan pemantauan. Pengukuran variabel SPI terdiri dari dua belas pernyataan yang diukur dengan skala Likert. Kualitas reviu LKPD diukur berdasarkan indikator sesuai Standar Reviu LKPD yaitu ruang lingkup reviu, waktu pelaksanaan reviu, kompetensi pereviu, tahapan reviu, kertas kerja reviu, dan pelaporan reviu. Instrumen pengukuran variabel kualitas reviu terdiri dari delapan pernyataan dan diukur dengan skala Likert.

Laporan keuangan yang berkualitas adalah laporan keuangan yang memenuhi syarat karakteristik kualitatif laporan keuangan, yaitu relevan, andal, dapat dibandingkan dan dapat dipahami. Variabel kualitas LKPD diukur berdasarkan karakteristik kualitatif laporan keuangan yang dijabarkan dalam sembilan pernyataan dan diukur dengan skala Likert.

Uji instrumen dilakukan atas data kuesioner menggunakan uji validitas dan uji reliabilitas kemudian dilakukan uji asumsi klasik, yaitu uji normalitas, uji multikolinieritas, uji linearitas dan uji heteroskedastisitas. Selanjutnya, data kuesioner dilakukan uji statistik yang terdiri dari analisis regresi linier, uji statistik $\mathrm{F}$ untuk menguji ketepatan model dan uji statistik $t$ untuk menguji hipotesis, dan terakhir dilakukan uji koefisien korelasi dan koefisien determinasi.

\section{HASIL DAN PEMBAHASAN}

Kuesioner yang dapat diolah sebanyak 83 dari 119 kuesioner yang disebar (69,75\%). Terdiri dari 43 orang laki-laki $(51,81 \%)$ dan 40 orang wanita (48,19\%). Sebanyak 61 orang (73,49\%) responden adalah pejabat fungsional pengawas sedangkan sisanya 22 orang $(26,51 \%)$ belum diangkat sebagai pejabat fungsional pengawas. Jumlah responden dengan latar belakang pendidikan akuntansi sebanyak 28 orang (33,73\%) dan 55 orang $(66,27 \%)$ lainnya berlatar belakang non-akuntansi. Berdasarkan data responden tersebut dapat dilihat bahwa inspektorat daerah belum sepenuhnya memperhatikan kompetensi yang dibutuhkan dalam mengisi jabatan aparat pengawas. Hal ini dapat dilihat dari jumlah responden yang berlatar belakang pendidikan akuntansi hanya sepertiga dari jumlah responden. Tabel 2 
Tabel 2. Data Demografi Responden

\begin{tabular}{lcc}
\hline \multicolumn{1}{c}{ Keterangan } & Jumlah & Persentase \\
\hline Jenis Kelamin & & \\
Pria & 43 & $51,81 \%$ \\
Wanita & 40 & $48,19 \%$ \\
\cline { 2 - 3 } Jumlah & 83 & $100,00 \%$ \\
\hline Jabatan & & \\
Jabfung Pengawas & 61 & $73,49 \%$ \\
Staf & 22 & $26,51 \%$ \\
Jumlah & 83 & $100,00 \%$ \\
\hline Latar Belakang Pendidikan & & \\
Akuntansi & 28 & $33,73 \%$ \\
Non-akuntansi & 55 & $66,27 \%$ \\
Jumlah & 83 & $100,00 \%$ \\
\hline
\end{tabular}

menampilkan data demografi responden. Dari hasil pengujian validitas instrumen menggunakan metode korelasi Pearson didapatkan 3 indikator yang tidak valid yaitu KA11, KL5 dan KL 9 sehingga harus direduksi. Pengujian reliabilitas instrumen dilakukan setelah mereduksi indikator yang tidak valid dan didapatkan nilai Cronbach's Alpha untuk semua variabel $>0,6$ yang artinya semua variabel reliabel (Tabel 3).

Dari pengujian asumsi klasik didapatkan hasil untuk semua uji memenuhi syarat, baik uji normalitas dengan Uji One-Sample Kolmogorov-Smirnov; uji multikolinieritas; uji linearitas dan uji heteroskedastisitas dengan Uji Glejser. Pengujian dilanjutkan untuk uji statistik, baik analisis regresi linier, uji statistik $F$, uji statistik $t$ dan uji koefisien korelasi dan koefisien determinasi.
Hasil analisis regresi linier berganda untuk model penelitian pertama didapatkan persamaan regresi linier berganda sebagai berikut:

$K R=\alpha_{1}+\beta_{1} K A+\beta_{2} K A+\beta_{3} K A+e$

$K R=2,683+0,313 K A+0,177 K O+0,215 S P I+e$

Untuk model penelitian kedua, didapatkan hasil analisis regresi linier sederhana dengan persamaan regresi linier sederhana sebagai berikut:

$\mathrm{KL}=\alpha_{2}+\beta_{4} \mathrm{KR}+\mathrm{e}$

$\mathrm{KL}=17,425+0,320 \mathrm{~K} \mathrm{R}+\mathrm{e}$

Hasil uji statistik $F$ didapatkan nilai $F$ hitung $=25,998>\mathrm{F}$ tabel $=2,720$ sehingga disimpulkan model regresi linier yang digunakan sebagai model penelitian adalah tepat. Hasil uji statistik $\mathrm{t}$ didapatkan untuk semua variabel independen pada model penelitian pertama dan model penelitian kedua nilai $\mathrm{t}$ hitung $>\mathrm{t}$ tabel $=1,990$ dengan

Tabel 3. Nilai Koefisien Cronbach's Alpha

\begin{tabular}{lcl}
\hline \multicolumn{1}{c}{ Variabel } & $\begin{array}{c}\text { Nilai Koefisien } \\
\text { Cronbach's Alpha }\end{array}$ & Kesimpulan \\
\hline Kompetensi (KA) & 0,646 & Reliable \\
\hline Komitmen Organisasi (KO) & 0,817 & Reliable \\
\hline Sistem Pengendalian Intern (SPI) & 0,926 & Reliable \\
\hline Kualitas Reviu (KR) & 0,841 & Reliable \\
\hline Kualitas LKPD (KL) & 0,655 & Reliable \\
\hline
\end{tabular}


nilai signifikansi $<0,05$ sehingga disimpulkan $\mathrm{H}_{1}, \mathrm{H}_{2}, \mathrm{H}_{3}$, dan $\mathrm{H}_{4}$ diterima. Tabel 4 menyajikan hasil uji statistik t.

Hasil uji koefisien korelasi dan koefisien determinasi didapatkan untuk model penelitian pertama, nilai koefisien korelasi sebesar 0,705 dengan nilai koefisien determinasi sebesar 47,8\%. Untuk model penelitian kedua didapatkan nilai koefisien korelasi sebesar 0,447 dengan nilai koefisien determinasi sebesar $20 \%$.

Tabel 4. Hasil Uji Statistik t

\begin{tabular}{l|c|c|c}
\hline \multicolumn{1}{c|}{ Ket } & $\mathrm{t}$ & Sig & Kesimpulan \\
\hline VD: KR & & & \\
KA & 3,997 & 0,000 & Diterima \\
KO & 2,183 & 0,032 & Diterima \\
SPI & 4,137 & 0,000 & Diterima \\
\hline VD: KL & & & \\
KR & 4,499 & 0,000 & Diterima \\
\hline
\end{tabular}

Hipotesis pertama $\left(\mathrm{H}_{1}\right)$ yang menyatakan bahwa kompetensi berpengaruh terhadap kualitas reviu diterima. Hal ini dapat diartikan bahwa tingginya kompetensi yang dimiliki oleh auditor APIP maka akan menghasilkan reviu yang berkualitas. Hasil penelitian ini senada dengan penelitian Amirullah et al. (2010) \& Eda, et al. (2017) bahwa kompetensi berpengaruh terhadap reviu atas LKPD. Kompetensi yang dimaksud adalah kompetensi yang terkait dengan pengetahuan, pendidikan dan pengalaman yang dimiliki oleh auditor APIP yang mendukung dalam melaksanakan reviu atas LKPD sehingga reviu dilaksanakan sesuai dengan standar dan menghasilkan rekomendasi yang tepat.

Hipotesis kedua $\left(\mathrm{H}_{2}\right)$ yang menyatakan bahwa komitmen organisasi berpengaruh terhadap kualitas reviu diterima. Hal ini berarti bahwa komitmen organisasi tinggi yang dimiliki oleh auditor APIP akan menghasilkan reviu yang berkualitas. Hasil ini senada dengan penelitian yang dilakukan Amirullah et al. (2010) bahwa komitmen organisasi berpengaruh terhadap pelaksanaan reviu. Adanya komitmen organisasi yang tinggi akan membuat auditor APIP mengerahkan semua kemampuan dan usahanya untuk melaksanakan tugasnya dengan baik sehingga dapat mencapai tujuan yang telah ditetapkan, termasuk dalam pelaksanaan reviu atas LKPD.

Hipotesis ketiga $\left(\mathrm{H}_{3}\right)$ yang menyatakan bahwa sistem pengendalian intern berpengaruh terhadap kualitas reviu diterima. Hal ini dapat juga diartikan bahwa dengan sistem pengendalian intern yang memadai dapat menghasilkan reviu yang berkualitas. Hasil ini senada dengan hasil penelitian yang telah dilakukan oleh Manaf et al. (2014) bahwa pemahaman sistem pengendalian intern berpengaruh terhadap proses reviu atas LKPD. Implementasi sistem pengendalian intern yang memadai dalam kegiatan reviu atas LKPD yang dilakukan oleh auditor APIP melalui kelima unsur pengendalian akan memberikan keyakinan bahwa tujuan reviu dicapai melalui kegiatan yang efisien dan efektif, pengamanan aset negara, keandalan pelaporan keuangan dan kepatuhan terhadap peraturan perundangan sehingga menghasilkan reviu yang berkualitas.

Hipotesis keempat $\left(\mathrm{H}_{4}\right)$ yang menyatakan bahwa kualitas reviu berpengaruh terhadap kualitas LKPD. Hal ini mengandung pengertian bahwa dengan dilaksanakan reviu yang berkualitas maka akan menghasilkan LKPD yang berkualitas juga. Hasil ini 
mendukung penelitian Manaf et al. (2014) bahwa proses reviu berpengaruh terhadap kualitas LKPD. Reviu yang berkualitas, yang sesuai dengan Standar Reviu, akan menghasilkan rekomendasi yang tepat sehingga dapat membantu dalam penyusunan LKPD yang berkualitas. Namun demikian, masih terdapat banyak faktor lain yang mungkin mempengaruhi kualitas LKPD. Hal ini dikarenakan reviu dilaksanakan oleh auditor APIP, yang tidak terlibat secara langsung dalam penyusunan LKPD.

\section{SIMPULAN}

Hasil pengujian menunjukkan bahwa variabel independen pada model penelitian pertama, yaitu kompetensi, komitmen organisasi dan sistem pengendalian intern berpengaruh terhadap kualitas reviu. Hasil pengujian pada model penelitian kedua menunjukkan bahwa kualitas reviu berpengaruh terhadap kualitas LKPD.

Penelitian ini masih terdapat keterbatasan yang mungkin bisa diantisipasi oleh peneliti selanjutnya yaitu kuesioner yang dapat diolah jumlahnya tidak sesuai yang diharapkan. Hal ini karena dalam penyebaran kuesioner, peneliti tidak memberikan penjelasan secukupnya kepada responden sehingga masih terdapat item pernyataan yang tidak diisi. Masalah waktu yang terbatas juga menjadi kendala peneliti dalam mengumpulkan kuesioner, karena responden yang merupakan aparat pengawas tidak selalu berada di tempat sehingga peneliti tidak dapat berinteraksi langsung dengan responden.

Berdasarkan keterbatasan penelitian tersebut, maka peneliti memberikan beberapa saran bagi peneliti selanjutnya agar penelitian selanjutnya dapat lebih sempurna, yaitu dalam melaksanakan penelitian sebaiknya peneliti memberikan penjelasan secukupnya dalam setiap item pernyataan sehingga dapat membantu persepsi responden agar sesuai yang diharapkan. Peneliti sebaiknya menyediakan waktu lebih atau memilih waktu yang longgar untuk menyebarkan kuesioner, khususnya apabila menggunakan aparat pengawas sebagai responden, dikarenakan mobilitas aparat pengawas yang cukup tinggi.

\section{DAFTAR PUSTAKA}

Alim, M. N., Hapsari, T. dan Purwanti, L. (2007). Pengaruh Kompetensi dan Independensi terhadap Kualitas Audit dengan Etika Auditor Sebagai Variabel Mediator. Simposium Nasional Akuntansi $X$. Makasar.

Amirullah, Darwanis \& Yahya, M. R. (2010). Pengaruh Kompetensi Auditor dan Komitmen Organisasi terhadap Implementasi Reviu atas Laporan Keuangan Pemerintah Daerah di Inspektorat Aceh. Jurnal Telaah \& Riset Akuntansi. Vol. 3 (2): 130-154.

Ashton, A.H. (1991). Experience and Error Frequency Knowledge as Potential Determinants of Audit Expertise. The Accounting Review. Januari. P. 72-92.

Eda, A., Karamoy, H.\& Gamaliel, H. (2017). Pengaruh Prosedur Reviu, Kompetensi dan Jangka Waktu Pelaksanaan Terhadap Kualitas Reviu Laporan Keuangan Pemerintah Daerah pada Inspektorat SeProvinsi Gorontalo. Jurnal Riset Akuntansi dan Auditing "Goodwill". Vol. 8 (1): 222-232.

Harahap, S. S. (2009). Analisis Kritis atas Laporan Keuangan. Jakarta: Raja Grafindo Perkasa. 
Kementerian Dalam Negeri. (2008). Peraturan Menteri Dalam Negeri Nomor 4 Tahun 2008 tentang Pedoman Pelaksanaan Reviu atas Laporan Keuangan Pemerintah Daerah. Jakarta.

Kementerian Keuangan. (2015). Peraturan Menteri Keuangan Nomor 8 Tahun 2015 tentang Standar Reviu atas Laporan Keuangan Pemerintah Daerah. Jakarta.

Manaf, I. A., Arfan, M., \& Darwanis. (2014). Pengaruh Pemahaman tentang Standar Akuntansi Pemerintahan dan Sistem Pengendalian Intern terhadap Proses Reviu Laporan Keuangan Pemerintah Daerah oleh Inspektorat dan Implikasinya terhadap Kualitas Laporan Keuangan Pemerintah Daerah pada Inspektorat Kabupaten/Kota di Provinsi Aceh. Jurnal Magister Akuntansi.Vol.3 (4): 23-35.

Marganingsih, A.\& Martani, D. (2010). Anteseden Komitmen Organisasi dan Motivasi: Konsekuensinya terhadap Kinerja Auditor Intern Pemerintah. Jurnal Akuntansi dan Keuangan Indonesia. Vol 7- No.1: 79-106.

Mowday, R. T., Steers, R. M., \& Porter, L. W. (1979). The Measurement of Organizational Commitment. Journal of Vocational Behavior. Vol 14: 224-247.

Nuryaman \& Christina, V. (2015). Metodologi Penelitian Akuntansi dan Bisnis Teori dan Praktik. Bogor: Ghalia Indonesia.

Pemerintah Republik Indonesia. (2003). Undang-Undang Nomor 17 Tahun 2003 tentang Keuangan Negara. Jakarta.

Pemerintah Republik Indonesia. (2004). Undang-Undang Nomor 15 Tahun 2004 tentang Pemeriksaan Pengelolaan dan Tanggung Jawab Keuangan Negara. Jakarta.

Pemerintah Republik Indonesia. (2006). Peraturan Pemerintah Nomor 8 Tahun 2006 tentang Pelaporan Keuangan dan Kinerja Instansi Pemerintah. Jakarta.

Pemerintah Republik Indonesia. (2008). Peraturan Pemerintah Nomor 60 Tahun 2008 tentang Sistem Pengendalian Intern Pemerintah. Jakarta.

Pemerintah Republik Indonesia. (2010). Peraturan Pemerintah Nomor 71 Tahun 2010 tentang Standar Akuntansi Pemerintahan. Jakarta.

Robbins, S.P. dan Judge, T.A. (2009). Organizational Behavior. 13th Edition. Person Education, Inc. New Jersey.

Tandiontong, M. (2016). Kualitas Audit dan Pengukurannya. Bandung: Penerbit Alfabeta.

Widyarini, K. (2015). Pengaruh Prosedur Reviu, Latar Belakang Pendidikan, Tekanan Waktu, dan Anggaran Dana Reviu pada Kualitas Reviu Laporan Keuangan Pemerintah Daerah (Studi Empiris pada Inspektorat Daerah di Provinsi Bali). Tesis. Universitas Udayana Denpasar.

Windsor, C.A. dan Ashkanasy, N.M. 1995. The Effect of Client Management Bargaining Power, Moral Reasoning Development, and Belief in a Just World on Auditor Independence.

Accounting, Organizations and Society. Vol 20 No.7/8. p. (701-720). 